\title{
Analisis Konfirmatory Faktor Pengukuran Indikator Kesejahteraan Rumah Tangga
}

\author{
Yulhendri \\ Program Studi Pendidikan Ekononi Fakultas Ekonomi \\ Universitas Negeri Padang \\ Email: Yulhendriunp@gmail.com \\ Nora Susanti \\ Program Studi Pendidikan Ekononi \\ STKIP PGRI Sumatera Barat \\ Email: bundafyra@yahoo.co.id
}

\begin{abstract}
Level Measurement of household welfare require multidimensional measurement. Based on the consideration of population specification and the distribution of population residence location, this research is determined by using multistage random sampling technique. The analysis tools usedis Lisrel 8.30 to get the CFA. This study aims to determine indicators of household welfare in physical and psychological aspects. The indicators that were analyzed are physical factors, safety factor, affection, appreciation and self-actualization. The results of this study indicated that the measurement factors sourced from physical well-being consistently can be used as a measurement of household welfare level. The measurementcan be used in aspects of production factors, income level, housing conditions, home facilities, health conditions, rice adequacy, protein adequacy,water adequacy, availability of transportation facilities. While the non-physical factors which can also be used as a measurement of welfare are a sense of security in preference to public order, anxiety and fear, the role of the head of the household in maintaining the household. A sense of affection is related to the affection of the household, mutual trust, belonging, and hospitality. Meanwhile, the reward factor does not qualify to be a measurement. Self-actualization can be in the form of participation and caring for others, obedience in paying zakat, and sedeqah.
\end{abstract}

Keywords: Household Welfare, Love, actualitation, assets phisik

\section{PENDAHULUAN}

Kesejahteraan individu dan rumah tangga amat ditentukan oleh kemampuan anggaran yang ia miliki. Kemampuan tersebut diperoleh dari sejumlah pendapatan sehingga secara material pendapatan merupakan salah satu faktor penentu tingkat kesejahteraan seseorang. Namun demikian, kecukupan kekayaan fisik belum tentuk memberikan kepuasan 
kepada rumah tangga, manusia sebagai makhluk sosial dihadapkan dengan aspek psikologis yang ada dalam dirinya. Aspek tersebut menyangkut potensi ruhaniah dan kejiwaan yang membedakan manusia dengan makhluk lain. Karena kompleksnya ukuran kesejahteraan tersebut beberapa ahli khususnya dalam lapangan kajian ekonomi mencoba menawarkan 2 pendekatan utama yakni pendekatan utility, marginality (Pigou, 1952, Sen, 1984). Pendekatan utilitas menekankan pada bagaimana pelaku ekonomi memaksimalkan kepuasan dengan menghabiskan fungsi dan kegunan barang (utility). Sementara itu pendekatan marginality menekankan pada perubahan input mempengaruhi output atau perubahan konsumsi mempengaruhi kepuasan.

Pengukuran tingkat kesejahteraan selama ini juga bisa dikategorikan sebagai ukuran objektif dan ukuran subyektif. Rettig dan Bubolz (1983) pun menyusun ukuran kesejahteraan dengan memadukan aspek ekonomi (objektif) dan non ekonomi (subyektif). Rettig dan Bubolz (1983) menguraikan indikator kesejahtaraan dalam bentuk kasih sayang (love), layanan (services), dan uang (money). Kasih sayang merupakan ekspresi dari penghargaan yang positif atau kenyaman atas komunikasi yang saling terbuka seperti kontak mata, sentuhan, persalaman, kedekatan dan ekspresi. Layanan merupakan keterlibatan secara sesama anggota keluarga sehingga menjadi lebih terbantu dan saling membutuhkan antara satu dengan yang lainnya, meningkatkan kenyaman dan menghemat energi yang digunakan masing-masing. Sementara uang merupakan stimulan atas peningkatan kesejahteraan, di mana uang menjadi alat untuk memenuhi kebutuhan fisik dan simbol perhatian antara sesama anggota keluarga.

Selanjutnya, Rettig bersama Leichtentritt

mengembangkan 3 pendekatan pengukuran kesejahteraan keluarga, yakni pendekatan teori lingkungan manusia (human ecological- system theory), teori sumberdaya (resources theory) dan teori perilaku (Facet theorybehaviora). Pendekatan teori lingkungan manusia menggambarkan hubungan ketergantungan manusia dengan lingkungan sekitarnya, seperti lingkungan fisik, biologis, sosial termasuk segala yang berkaitan dengan transformasi energi dan sumberdaya informasi. Dalam teori sumberdaya, kesejahteraan keluarga dihitung atas kenyaman keluarga, informasi yang diperoleh, serta kepemilikan sejumlah uang, barang dan jasa. Sementara itu dalam teori Facet., kesejahteraan keluarga dihitung dengan skala yang beragam dengan persepsi individu dalam keluarga tentang kesejahteraannya.

Berdasarkan teori

sumberdaya (resources) yang dikembangkan FAO, Rettig dan Leichtentrictt 
dikembangkanlah 6 acuan pengukur tingkat kesejahteraan keluarga, yakni : (a) cinta dan kasih sayang (love and affection); (b) hormat dan saling menghargai (respect and esteem) (status); (c) Kenyamanan dan saling membantu (comfort and assistance) (services); komunikasi dan saling berbagi (communication resulting in shared meaning (information); kepemilikan barang (ownership of personal things (goods); and (f) dan uang dan penggunaannya oleh individu (money for personal use (money).

Penelitian ini mencoba mengadopsi dan meramukan beberapa teori ekonoi dengan teori psikologis dalam aspek pengukuran kesejahteraan. Teori kesejahteraan (walfare theory) pada umumnya diadopsi dari teori Adam Smith dalam bukunya The Wealth of Nation (1776), bahwa individu memiliki hastrat untuk memenuhi keinginannya dan kebutuhannya. Dengan kecenderungan individu untuk selalu berusaha memuaskan keinginannya, maka kesejahteraan akan dicapai pada saat kepuasan mencapai tingkat optimum. Pencapaian tingkat kepuasan inilah yang menjadi kajian ilmuan ekonomi. Berbagai pendekatan dapat menjelaskan bagaimana individu atau rumah tangga dapat dikatakan "sejahtera" atau "puas", diantaranya adalah pendekatan marginality, utility, efisiensi pasar, dan opportunity cost (Case,2003).

Melanjutkan penjelasan Case (2003) tentang kesejahteraan dalam pendekatan utilitas, maka peneliti menelusuri kajian literatur terkait dengan kesejahteraan rumah tangga keluarga. Dalam konteks keluarga (family) kesejahteraan merupakan suatu kondisi dimana keluarga mencapai tingkat kepuasaan maksimal. Individu dalam suatu keluarga akan puas atau sejahtera jika keinginannya dapat terpenuhi oleh orang tua sebagai kepala keluarga, individu juga akan merasa sejahtera jika terbentuk hubungan harmonis dalam keluarga. Sementara itu dalam teori psikologi tingkat dan ukuran kesejahteran itu dapat diukur berdasarkan pencapaian tingkatan (hierarchy) pemenuhan kebutuhan Maslow (1954, dalam Huitt, 2004). Dalam pendekatan itu, Maslow membagi kebutuhan manusia menjadi 5 tingkatan, yaitu : 1) Kebutuhan fisiologis, yaitu kebutuhan dasar, seperti rasa lapar, haus, tempat berteduh, seks, tidur, oksigen, dan kebutuhan jasmani lainnya; 2) Kebutuhan akan rasa aman, antara lain meliputi keselamatan dan perlindungan terhadap kerugian fisik dan emosional; 3) Kebutuhan sosial, meliputi kebutuhan akan rasa memiliki dan dimiliki, kasih sayang, diterima-baik, dan persahabatan; 4) Kebutuhan akan penghargaan, seperti faktor penghormatan internal seperti harga diri, otonomi, dan prestasi; serta faktor eksternal seperti status, pengakuan, dan perhatian; dan 5) Kebutuhan akan aktualisasi diri: mencakup hasrat untuk makin menjadi diri sepenuh kemampuannya sendiri, menjadi apa saja menurut kemampuannya. 
Berdasarkan pendekatan Maslow itu maka tingkat kesejahteraan merupakan pencapaian pemenuhan kelima kebutuhan itu.

\section{Motivasi Penelitian}

Kesejahteraan dalam bentuk kecukupan konsumsi, pendidikan anak yang lebih baik, keserasian dan keharmonisan dalam rumah tangga dan eksistensi anggota rumah tangga dalam jangka panjang merupakan tujuan rumah tangga dalam proses kehidupan ekonomi, maka dengan mengetahui faktor-faktor yang menjadi ukuran kesejateraan rumah tangga di masa mendatang maka rumah tangga bisa memilih perilaku yang tepat untuk berperilaku secara ekonomi, dan sosial khususnya tentang belajar. Dan bagi peneliti lanjutan bisa menjadi rujukan emperis tentang dimensi dan indikator kesejahteraan rumah tangga

\section{Tujuan Penelitian}

Penelitian ini bertujuan untuk menjelaskan tentang faktor-faktor yang bisa dijadikan sebagai indikator dalam membentuk tingkat kesejahteraan :

1. Apakah kepemilikan kekayaan fisik bisa dijadikan sebagai ukuran tingkat kesejahteraan keluarga

2. Apakah rasa aman bisa dijadikan sebagai indikator tingkat kesejahteraan rumah tangga

3. Apakah rasa kasih sayang dan saling menyayangi bisa dijadikan indikator kesejahteraan rumah tangga
4. Apakah penghargaan dan saling menghargai bisa dijadikan sebagai tingkat kesejaheraan

5. Apakah aktualisasi diri bisa dijadikan sebagai indikator tingkat kesejahteraan rumah tangga

\section{KAJIAN PUSTAKA}

Berbagai kajian tentang berkembang secara teoretis dan emperis. Kesejahteraan merupakan tujuan kehidupan. Hal inilah yang menjadi sumber inspirasi dan motivasi bergerak, karena dengan tercapainya tingkat kesejahteraan maka kehidupan terasa lebih bermakna dan bermartabat. Berbagai upaya dilakukan oleh individu untuk mencapai tingkat kesejahteraan tersebut.

Kesejahteraan merupakan salah satu konsep dalam ilmu ekonomi yang sering menjadi bahan kajian dan penelitian. Teori kesejahteraan (walfare theory) pada umumnya mengadopsi dari teori Adam Smith dalam bukunya The Wealth of Nation (1776), bahwa individu memiliki hastrat untuk memenuhi keinginannya dan kebutuhannya. Ada kecenderungan individu akan selalu berusaha untuk memuaskan keinginan tersebut. Maka kesejahteraan itu dicapai pada saat kepuasan itu bisa tercapai secara optimum. Pencapaian tingkat kepuasan inilah yang menjadi kajian ilmuan ekonomi. Berbagai pendekatan bisa menjelaskan bagaimana individu atau rumah tangga bisa dikatakan "sejahtera" 
atau "puas". Diantaranya adalah pendekatan marginality, utility, efisiensi pasar, dan opportunity cost (Case,2003).

Pendekatan marginality, lebih cenderung menekankan pada upaya rumah tangga menambah unit barang dan jasa yang dikonsumsi untuk mempertinggi kesejahteraan, setiap penambahan satu unit barang dan jasa yang dihabiskan kegunaannya maka akan bertambah kepuasan seseorang sampai pada titik tertentu. Termasuk juga pada perilaku produsen, setiap input yang ditambahkan akan meningkatkan produk yang akan dihasilkan sehingga sampai pada titik tertentu.

Pendekatan efesiensi pasar, sebenarnya lebih cenderung pada bagaimana pasar bisa menciptakan surplus produsen dan surplus konsumen. Nicholson (2002) menjelaskan bahwa kepuasan atau kesejahteraan rumah tangga khususnya pada rumah tangga konsumen, kesejahteraannya dapat diukur dengan surplus konsumen. Dimana ukuran nilai lebih yang diterima oleh konsumen dari suatu barang yang dibeli melebihi dari yang mampu dibayar, atau harga dipasar lebih rendah dibandingkan dengan daya beli konsumen. Sementara itu produsen mendapatkan surplus ketika nilai lebih yang diterima oleh produsen dari suatu produk melebihi dari biaya oportunitas (opportunitiy cost) yang muncul karena memproduksi barang itu. Mencerminkan berapa biaya yang secara sukarela bersedia dibayar oleh para produsen demi mendapatkan hak menjual suatu produk pada harga pasar yang berlaku. Dalam pendekatan utilitas ukuran kesejahteraan rumah tangga ditentukan oleh anggaran yang dimiliki oleh individu dan rumah tangga, semakin tinggi garis anggaran maka semakin tinggi kemungkinan kepuasan rumah tangga dalam melakukan konsumsi. Hampir senada dengan itu, Pindyk (2005) menjelaskan surplus konsumen diartikan sebagai selisih dari berapa yang tersedia untuk dibayar oleh konsumen untuk suatu barang dengan berapa yang sebenarnya dibayar oleh konsumen ketika membeli barang tersebut. Dan surplus produsen didefenisikan sebagai jumlah semua unit yang diproduksi dari selisih antara harga pasar barang tersebut dan biaya marjinal produksinya.

Dalam pendekatan efisiensi pasar, kesejahteraan itu merupakan surplus yang dinikmati oleh konsumen tatkala terjadi selisih lebih antara anggaran yang dimiliki untuk membeli sesuatu barang dan jasa dengan harga barang dan jasa riil yang diciptakan pasar. Sementara itu kesejahteraan produsen terjadi tatkala terdapat selisih lebih antara penjualan dengan biaya untuk menghasilkan barang dan jasa atau harga pokok produksi atau harga pokok penjualan. Namun Case (2003) menjelaskan seorang individu memilih berdasarkan fungsi utilitasnya sendiri, atau berdasarkan ukuran kemakmurannya sendiri, sementara itu masyarakat atau komunitas memilih berdasarkan 
fungsi kemakmuran sosial yang mampu mewujudkan etika masyarakat itu. Namun kekayaan bukanlah ukuran yang bisa digunakan untuk mengukur kemakmuran yang sempurna.

Kesejahteraan

dapat dipandang dalam dua sisi, yakni sisi rumah tangga konsumen dan sisi yang lain pada sisi rumah tangga produsen. Pada rumah tangga konsumen tingkat kesejahteraan itu diukur dari tingkat kepuasan individu dalam memakai atau menghabiskan nilai guna barang (utility). Sementara itu di sisi produsen, tingkat kepuasan itu diukur dari tingkat keuntungan atau dikenal juga dengan beberapa istilah diantaranya surplus, benefit, laba yang akan diperoleh produsen pada saat menambah satu input produksi, atau dikenal dengan istilah marginality.

Melanjutkan penjelasan Case (2003) tentang kesejahteraan dalam pendekatan utilitas maka peneliti menelusuri kajian literatur yang berkaitan dengan kesejahteraan rumah tangga keluarga. Dalam keluarga terdiri dari beberapa orang individu yang memiliki fungsi kesejahteraan masing-masing. Individu akan dalam keluarga akan puas atau sejahtera jika, keinginan dirinya bisa terpenuhi oleh orang tua sebagai kepala keluarga, individu juga akan merasa sejahtera jika hubungan yang saling harmonis dalam keluarga.

Dalam konteks keluarga (family) kesejahteraan merupakan suatu kondisi dimana keluarga mencapai tingkat pencapaian kepuasaan maksimal. Tingkat kesejahteran juga bisa diukur dari pencapaian tingkatan (hierarchy) pemenuhan kebutuhan Maslow (1954, dalam Huitt, 2004). Rettig dan Bubolz (1983) menyusun pengukuran kesejahteraan keluarga dengan menggabungkan aspek ekonomi dan non ekonomi (sosial, psikologi). Pengintegrasian ini menggabungkan faktor ekonomi dan non ekonomi dalam mengukur tingkat kesejahteraan keluarga. Khususnya dampak psikologis atas suatu interaksi keluarga dengan anggota keluarga yang lain dan respon atas kepemilikan sumberdaya yakni uang, barang dan jasa.

Lebih lanjut Rettig dan Bubolz (1983) menguraikan tentang indikator kesejahtaraan dalam bentuk kasih sayang (love), Layanan (services), uang (money). Kasih sayang merupakan ekspresi dari penghargaan yang positif atau kenyaman atas komunikasi yang saling terbuka seperti kontak mata, sentuhan, persalaman, kedekatan dan ekspresi. Layanan merupakan keterlibatan secara sesama anggota keluarga sehingga menjadi lebih terbantu dan saling membutuhkan antara satu dengan yang lainnya, meningkatkan kenyaman dan menghemat energi yang digunakan oleh masing-masing. Sementara itu uang merupakan stimulan atas peningkatan kesejahteraan, dan uang menjadi alat untuk memenuhi kebutuhan fisik dan simbol perhatian antara sesama anggota keluarga. 
Rettig dan Leichtentritt (1999) mengembangkan 3 pendekatan yang bisa digunakan untuk mengukur kesejahteraan keluarga, yakni dengan pendekatan teori Lingkungan manusia (human ecological- system theory), Teori sumberdaya (resources theory) dan teori perilaku (Facet theorybehaviora). Dalam pendekatan human ecological interaksi dan hububngan ketergantungan manusia dengan lingkungan fisik, biologis, sosial termasuk hal-hal yang berkatian dengan transformasi energi dan sumberdaya informasi. Dalam teori sumberdaya kesejahteraan keluarga tersebut dihitung dengan kenyaman keluarga, informasi yang diperoleh, kepemilikan sejumlah uang, barang dan jasa. Sementara itu dalam teori Facet teori, kesejahteraan keluarga dihitung dengan skala yang beragam dengan persepsi individu dalam keluarga tentang kesejahteraannya.

Dalam teori sumberdaya (resources) yang dikembangkan oleh FAO, Rettig dan Leichtentrictt (1999) mengembangkan 6 ukuran yang bisa dijadikan sebagai acuan untuk menentukan tingkat kesejahteraan keluarga yakni (a) cinta dan kasih sayang (love and affection) (b) hormat dan saling menghargai (respect and esteem) (status), (c) Kenyamanan dan saling membantu (comfort and assistance) (services), komunikasi dan saling berbagi (communication resulting in shared meaning (information), (e) kepemilikan barang (ownership of personal things (goods), and (f) dan uang dan penggunaannya oleh individu (money for personal use (money).

Mengadopsi hirarki kebutuhan menurut Maslow (1954, dalam Huitt, 2004) Maslow membagi tingkat kebutuhan manusia menjadi sebagai berikut: 1) Kebutuhan fisiologis: kebutuhan yang dasariah, misalnya rasa lapar, haus, tempat berteduh, seks, tidur, oksigen, dan kebutuhan jasmani lainnya. 2) Kebutuhan akan rasa aman: mencakup antara lain keselamatan dan perlindungan terhadap kerugian fisik dan emosional. 3) Kebutuhan sosial: mencakup kebutuhan akan rasa memiliki dan dimiliki, kasih sayang, diterima-baik, dan persahabatan. 4) Kebutuhan akan penghargaan: mencakup faktor penghormatan internal seperti harga diri, otonomi, dan prestasi; serta faktor eksternal seperti status, pengakuan, dan perhatian. Dan 5) Kebutuhan akan aktualisasi diri: mencakup hasrat untuk makin menjadi diri sepenuh kemampuannya sendiri, menjadi apa saja menurut kemampuannya. Sehingga tingkat kesejahteraan itu diartikan sebagai pencapaitan pemenuhan kebutuhan-kebutuhan tersebut. Dan pendekatan yang bisa juga digunakan untuk menilai kesejahteraan adalah dengan menggunakan pendekatan Facet theory. Dimana individu atau keluarga bisa menentukan dan menilai tingkat kesejahteraannya sendiri. Pendekatan facet teori ini biasanya digunakan untuk mengukur dan menganalisis data 
pada penelitian perilaku (Hornik, 2007). Dalam pendekatan konsumsi, badan pemerintah seperti BPS, BKKBN, (dalam Cahyat, 2004) menguraikan tingkat kesejahteraan rumah tangga itu bisa di ukur dari beberapa indikator diantaranya adalah Memiliki tabungan keluarga, Makan bersama sambil berkomunikasi, Mengikuti kegiatan masyarakat, Rekreasi bersama (6 bulan sekali), Meningkatkan pengetahuan agama, Memperoleh berita dari surat kabar, radio, TV,dan majalah dan Menggunakan sarana transportasi. Kemudian BKKBN menambahkan tingkat sejahtera III Plus ditambahkan dengan Aktif memberikan sumbangan material secara teratur dan aktif sebagai pengurus organisasi

kemasyarakatan.

Sementara itu dalam konteks lokal di Indonesia Cahyat (2007) mendefenisikan kesejahteraan tersebut dalam tiga pengertian yakni: (1) Kesejahteraan subjektif (subjectivewellbeing atau disingkat SWB), (2) Kesejahteraan inti (kebutuhan dasar, seperti kekayaan materi, pengetahuan dan kesehatan), dan (3) Lingkungan pendukung (konteks). Perasaan kesejahteraan subjektif adalah kumpulan perasaan seseorang; bisa berupa perasaan sejahtera, rasa bahagia, rasa dihormati, rasa diakui, rasa miskin, rasa serba kekurangan, dan perasaan-perasaan sejenisnya. Perasaan ini bersifat sangat umum dan dipengaruhi oleh seluruh aspek kehidupan. Perasaan ini bisa saja bersifat sementara dan mungkin dipengaruhi oleh kejadian-kejadian sesaat. Kesejahteraan inti terdiri dari kebutuhan dasar yang bersifat material (kebendaan) maupun bukan material, yang mencakup aspek gizi dan kesehatan, pengetahuan, dan kekayaan materi. Lingkungan pendukung (konteks) adalah lingkungan kehidupan yang mempengaruhi kesejahteraan inti

Jadi dari berbagai teori diatas dapat dikategorikan bahwa tingkat kesejahteraan itu diukur dari tercapainya tingkat kebutuhan manusia mulai dari kebutuhan fisik sampai pada pemenuhan kebutuhan aktualisasi diri (satisfaction) atas benda atau kekayaan yang dimiliki. Dalam ukuran psikologis, kalau mengadopsi teori hirarki kebutuhan menurut Maslow maka tingkat kesejahteraan keluarga juga bisa diukur dari 4 hal yakni 1) rasa aman, 2) rasa kasih sayang atau sosial 3) rasa penghargaan dan 4 ) aktualisasi dari. Dalam aplikasi manajemen sesungguhnya teori motivasi Malow ini sudah sangat banyak diterapkan dan diteliti dalam mempertinggi tingkat kinerja karyawan. Namun penelitian berkaitan dengan ini pada aspek rumah tangga khususnya rumah tangga petani, nelayan dan pedagang masih amat terbatas.

\section{METODE PENELITIAN}

Penelitian ini merupakan penelitian kuantitatif. Populasi dari penelitian ini adalah kepala rumah tangga petani, nelayan, dan pedagang yang telah memiliki umur 
lebih dari 40 tahun. Populasi berada di daerah pantai yakni di Kabupaten Pesisir Selatan, Kabupaten Padang Pariaman dan Kota Padang. Sampel sebanyak 156 dan memenuhi kelayakan analisis sebanyak 147 cases. Penelitian ini menggunakan teknik Analisis konfirmator faktor (Confirmatory Factor Analysis). Untuk memudahkan hasil output peneliti menggunakan program sofware Lisrell versi 8,3 for windows. Confirmatory factor Analysis (CFA) merupakan alat analisis yang digunakan untuk menguji melihat pola hubungan yang telah memiliki landasan teori, dan output yang diperoleh merupakan pengujian hipotesis yang didukung oleh bukti emperik (Zaini,1993). Kecocokan model (goodness of fit) bisa dilihat dari nilai GFI, nilai chi-square dan nilai $p$ (probabilitas) makin rendah Chisquare dan makin tinggi nilai $p$-nya akan semakin baik.

\section{HASIL PENELITIAN}

Variabel kesejahteraan dibangun dengan 5 Variabel terukur yakni kesejahteraan material, rasa aman, rasa sayang dan saling mencintai, dan aktualisasi diri. Pada awalnya penghargaan juga dimasukkan dalam menentukan tingkat kesejahteraan namun faktor loadingnya tidak cukup memadai dibawah $\leq 0,50$ untuk menerima sebagai indikator yang reliabel.

Variabel-variabel yang menjadi pokok pembahasan dalam penelitian ini adalah kesejahteraan rumah tangga Kriteria yang dipakai dalam penentuan validitas model pengukuran variabel terukur yakni standardized loading factor $>1,96$ dan standardized loading factor > 0,50 (Hair,2006).

Kalau diperhatikan dari indeks GOF-nya sebagian besar baik, dimana nilai Chi-Square 11.75 $(P=0.038)$, GFI $0,97>0,90$, CFI $0,99>0,90$, IFI $0,99>$ dari 0,90 . Selanjutkan kalau diperhatikan nilai faktor loading dari masing-masing variabel terukur terhadap laten variabel tingkat kesejahteraan, dapat dilihat dari tabel berikut ini.

Tabel 4.1 : Evaluasi Kriteria Goodness of Fit Index Variabel Kesejateraan( $\eta 3)$

\begin{tabular}{|l|l|l|l|}
\hline \multicolumn{1}{|c|}{ Goodness of fit Index } & $\begin{array}{c}\text { Cut Off } \\
\text { Value }\end{array}$ & Output & Keterangan \\
\hline$\chi^{2}$ (Chi-Square & Kecil & 11,75 & Baik \\
\hline Probabilitas & $\geq 0,05$ & 0,038 & Kurang baik \\
\hline AGFI (Ajusted Goodness of index) & $\geq 0,90$ & 0,91 & Baik \\
\hline GFI (goodness of fit) & $\geq 0,90$ & 0,97 & Baik \\
\hline NNFI (Non-Normed fit index) & $\geq 0,90$ & 0,98 & Baik \\
\hline IFI (Incremental fit Index) & $\geq 0,90$ & 0,99 & Baik \\
\hline RMSE & $\leq 0,08$ & 0,093 & Kurang baik \\
\hline
\end{tabular}

Sumber: data diolah, 2010 
Nilai t muatan faktor (loading factor) lebih besar dari nilai kritis > 1,96. Angka ini menunjukkan reliabilitas atau konsistensi pengukuran kesejahteraan. Indikator kesejahteraan pada awalnya dibangun 5 variabel yang teramati namun variabel penghargaan tidak masuk dalam persyaratan ukuran realibilitas pengukuran. Nilai muatan faktornya lebih kecil dari nilai kritis yakni 23,63 kecil dari 1,96 dan faktor loadingnya hanya $-1,00$ kecil dari 0,50 sebagai persyaratan konsistensi pengukuran konstruk laten. Sehingga dalam pemodelan dihapus dalam proses analisis data.

Tabel 4.2 : Loading faktor $(\lambda)$ Pengukuran Variabel Tingkat Kesejahteraan

\begin{tabular}{|l|c|l|lll|}
\hline Variabel & $\begin{array}{l}\text { Loading } \\
\text { factor } \\
(\lambda)\end{array}$ & $\begin{array}{l}\text { Nilai t } \\
\text { hitung }\end{array}$ & Keterangan & & \\
\hline Y1 $\Rightarrow$ Kondisi Fisik & 0,17 & 2,16 & $\begin{array}{l}\text { Lebih besar dari } \\
\text { signifikan }\end{array}$ & 1,96 \\
\hline Y2 $\Rightarrow$ Rasa Aman & 0,85 & 13,24 & $\begin{array}{l}\text { Lebih besar dari } \\
\text { signifikan }\end{array}$ & 1,96 \\
\hline Y3 $\Rightarrow$ Kasih Sayang & 0,92 & 14,87 & $\begin{array}{l}\text { Lebih besar dari } \\
\text { signifikan }\end{array}$ & 1,96 \\
\hline Y4 $\Rightarrow$ Penghargaan & -1.00 & -17.31 & Kecil dari 1,96 tidak diterima \\
\hline Y5 $\Rightarrow$ Aktualisasi diri & 0,76 & 11,16 & $\begin{array}{l}\text { Lebih besar dari 1,96 } \\
\text { signifikan }\end{array}$ \\
\hline
\end{tabular}

Sumber: Data primer diolah, 2010.

Setelah dilakukan konfirmasi ternyata variabel penghargaan tidak memenuhi syarat untuk dijadikan sebagai salah satu ukuran tingkat kesejahteraan. Maka variabel tersebut dihapus dari analisis lanjutan. Dan berikut ini disajikan kembali hasil analisis CFA emperik variabel tingkat kesejahteraan.

Gambar 4.1 : Model Awal CFA Variabel Kesejahteraan 
Dari gambar baru tersebut terlihat bahwa variabel fisik, memiliki faktor loading 0,22 dan sebenarnya tidak memenuhi persyaratan $>0,50$ namun karena nilai $T$ nya 2,59 dan setelah dilakukan analisis model secara keseluruhan dapat memenuhi diatas $>$ 0,50 maka tetap dipertahankan.

Kemudian untuk menentukan CFA variabel ini memiliki tingkat reliabelitis yang baik, maka perlu dihitung Costruct reliability-nya (CR) dengan rumus sebagai berikut:

$$
\mathrm{CR}=\frac{(\Sigma \text { std loading })^{2}}{(\Sigma \text { std loading })^{2}+\Sigma \text { ej }}
$$

Jika nilai $C R \geq$ dari 0,70 maka reliabilitas model dinilai baik (wijanto,2008) dan Ve dihitung dengan rumus sebagai berikut: Dari perhitungan manual yang dilakukan $\mathrm{CR}=13,69 / 15,49=0,88>0,70$ sehingga bisa disimpulkan variabel tingkat kesejahteraan dapat dikatakan reliabel.

Berikut ini disajikan nilai loading faktor dari masing-masing item untuk pengukuran tingkat kesejahteran sebagai persyaratan asumsi SEM dan sebagai syarat untuk meneruskan analisis melalui program Lisrel 8,30 for windows.

Tabel 4.3 : Nilai Faktor Loading dari Indikator, Variabel Kesejahteraan Fisik

\begin{tabular}{|c|c|c|c|}
\hline Variabel & Dimensi & Indikator & $\begin{array}{c}\text { Nilai } \\
\text { Faktor } \\
\text { Loading }\end{array}$ \\
\hline \multirow[t]{3}{*}{$\begin{array}{l}\text { Kesejahteraan } \\
\text { Rumah } \\
\text { Tangga }\end{array}$} & $\begin{array}{l}\text { 1. Kondisi Fisik } \\
\text { 2. Tingkat } \\
\text { Pendapatan } \\
\text { Perbulan }\end{array}$ & $\begin{array}{l}\text { Faktor produksi } \\
\text { Tingkat Pendapatan }\end{array}$ & $\begin{array}{l}0,79 \\
0,95\end{array}$ \\
\hline & $\begin{array}{r}\text { 3. Kondisi Sarana } \\
\text { Tempat tinggal }\end{array}$ & $\begin{array}{l}\text { a. Kondisi Rumah } \\
\text { b. Fasilitas rumah }\end{array}$ & $\begin{array}{l}0,85 \\
0,64\end{array}$ \\
\hline & 4.Kesehatan & Kondisi Kesehatan & 0,62 \\
\hline
\end{tabular}




\begin{tabular}{|c|c|c|}
\hline \begin{tabular}{|l} 
5.Gizi dan \\
Makanan \\
(adopsi dari \\
Cahyat,2009) \\
namun di \\
modifikasi \\
sesuai dengan \\
kebutuhan \\
penelitian \\
termasuk skala \\
\\
6.Sarana \\
Transportasi
\end{tabular} & $\begin{array}{l}\text { a. Kecukupan lama } \\
\text { ketersediaan Beras } \\
\text { b. Kecukupan Protein } \\
\text { c. Kecukupan air } \\
\text { bersih sarana } \\
\text { d. Ketersediaan } \\
\text { transportasi pribadi. }\end{array}$ & 0,98 \\
\hline $\begin{array}{l}\text { 6.Tabungan } \\
\text { (Assets } \\
\text { Cadangan) }\end{array}$ & $\begin{array}{l}\text { a.Kecukupan tabungan atau } \\
\text { assets cadangan (dalam } \\
\text { bentuk uang tunai, } \\
\text { tabungan bank, emas, } \\
\text { logam berharga, dan assets } \\
\text { lainnya untuk darurat } \\
\text { seperti Berobat ke rumah } \\
\text { sakit }\end{array}$ & 1,38 \\
\hline
\end{tabular}

Sumber: Data primer diolah, 2010.

Tabel 4.4 : Nilai Faktor Loading dari Indikator, Variabel Kesejahteraan, Non Fisik

\begin{tabular}{|c|c|c|c|}
\hline Variabel & Dimensi & Indikator & $\begin{array}{l}\text { Nilai } \\
\text { Faktor } \\
\text { Loading }\end{array}$ \\
\hline \multirow[t]{2}{*}{$\begin{array}{l}\text { Kesejahteraan } \\
\text { Rumah } \\
\text { Tangga }\end{array}$} & Rasa Aman & 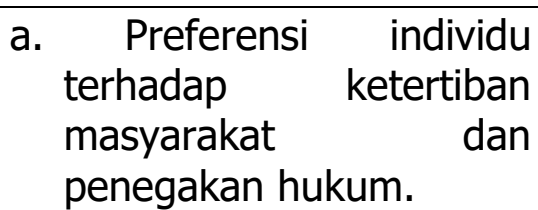 & $\begin{array}{l}0,65 \\
0,51\end{array}$ \\
\hline & & $\begin{array}{l}\text { c. Preferensi individu } \\
\text { terhadap peranannya } \\
\text { dalam menjaga anggota }\end{array}$ & 0,43 \\
\hline
\end{tabular}




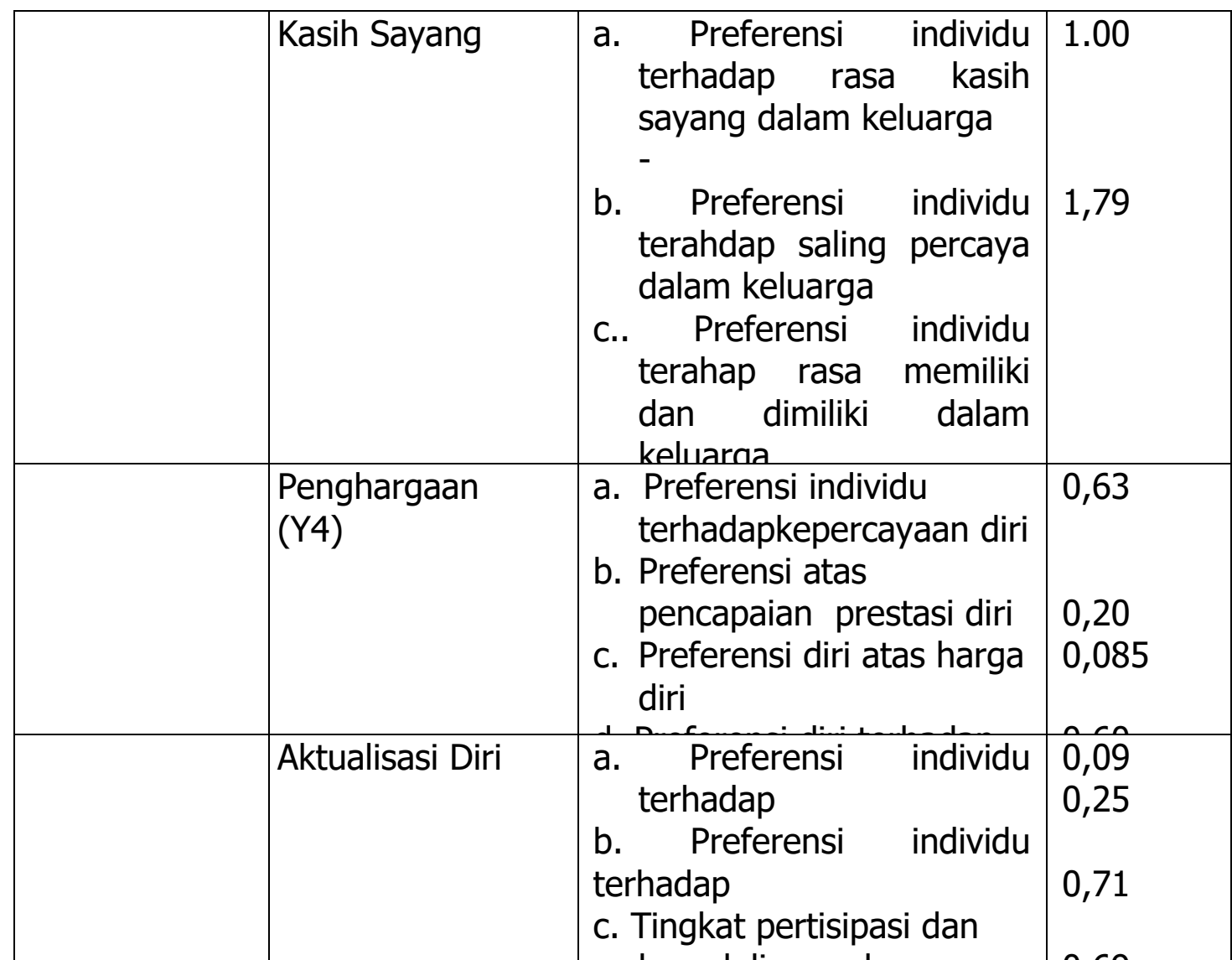

Sumber: data primer diolah, 2010

\section{Pembahasan}

Indikator

tingkat

kesejahteraan keluarga menurut Rettig dan Leichtentritt (1998) diawali dari logika bahwa indikator kesejahteraan keluarga itu adalah kepuasan antar anggota keluarga dan antar pasangan, dan kemudian dikembangkan lebih mendalam hubungan manusia dengan lingkungan, yakni berkaitan dengan rasa kasih sayang, ketersediaan uang, barang dan jasa secara berbagi informasi termasuk didalamnya tentang hubungan sosial. Maka peneliti juga mengadopsi teori kebutuhan menurut Maslow (1954) dalam bukunya tentang " $A$ Theory of human motivation" mengenalkan lima tingkatan dasar kebtuhan manusia yang diurutkan berdasarkan kepentinganya yakni kebutuhan fisiologis, kebutuhan keselamatan dan keamanan, kasih sayang dan persahabatan, kebutuhan harga diri dan yang paling tinggi kebutuhan rasa aktualisasi diri.

Sementara itu ilmu ekonomi menjelaskan bagaimana upaya manusia untuk memenuhi kebutuhan. Logika sederhana yang dirumuskan adalah ketika manusia telah memenuhi kebutuhannya maka tentu saja kesejahteraannya tercapai. Dalam bab IV telah diuraikan temuan penelitian, 
sebagian menerima hipotesis dan sebagian lainnya tidak menerima Untuk ini diperlukan pembahasan dan diskusi yang lebih mendalam. Pembahasan ini berkaitan dengan kajian tentang data emperik, hasil pengolahan, model alternatif dan rujukan referensi lanjutan yang diperlukan untuk membahas lebih mendalam tentang variabel penelitian tersebut. Kesejahteraan keluarga, dalam bentuk kondisi fisik, berupa: 1) kepemilikan faktor produksi, 2) Tingkat Pendapatan 3) Kondisi saran tempat tinggal, 4) kondisi kesehatan, 5) gizi dan makanan, 6) Sarana transportasi dan 7) Tabungan dan investasi. Kalau diperhatikan indikator tingkat kesejahteraan rumah tangga dalam penelitian ini menggambarkan kondisi tingkat yang cukup tinggi yakni $70,8 \%$, dari skor tertinggi 5 , rata-rata tingkat kesejahteraan keluarga berada pada level 3,14. Artinya secara relatif rumah tangga ini memiliki kekayaan fisik yang tidak terlalu rendah. Misalnya pada indikator tingkat penghasilan ratarata rumah tangga memiliki penghasilan $\quad \mathrm{Rp} 1.884 .000$ perbulan, nilai ini sama dengan 2 kali lipat tingkat UMR Provinsi Sumatera Barat.

Hasil analisis statistik deskriptif menunjukkan bahwa tingkat kesejahteraan secara umum dapat dikategorikan cukup tinggi secara fisik dan aktualisasi diri dan rumah tangga berada dalam keadaan situasi yang baik pada kondisi rasa aman, saling sayang menyayangi dan rasa penghargaan dan saling menghargai dalam keluarga.
Dimana secara umum tingkat capaian skor responden berada pada tingkat 0,708 atau 70,8\%. Dari skor terendah 1 dan tertinggi 5, diperoleh hasil nilai rata-rata 3,11 pada kondisi fisik, 4,12 kondisi rasa aman, 3,90 rasa saling mencintai dan menyayangi, 3,79 pada rasa saling menghargai dan penghargaan, dan 3,45 pada aktualisasi diri.

Penelitian tingkat kesejahteraan ini sesungguhnya mengabungkan antara pendekatan pengukuran bentuk fisik (material) dan psikologis (utilities). Walaupun diakui penggabungan itu kesulitan dalam pengukuran namun paling tidak penelitian ini menggambarkan tingkat kesejahteraan lebih kompleks. Secara material seseorang yang memiliki mobil dengan seseorang dengan memiliki sepeda motor bisa jadi dalam bentuk ukuran nilai finansial harga mobil jauh lebih besar dibandingkan dengan harga sepeda motor namun kalau dibandingkan tingkat kepuasan antara satu keluarga dengan keluarga lain nilai sepeda motor bisa jadi jauh lebih besar. Hal ini karena dikarenakan oleh preferensi dan ekspektasi seseorang terhadap barang tersebut dan barang lain serta anggaran (income) yang dimilikinya. Jika seseorang atau sebuah keluarga memiliki penghasilan yang hanya cukup untuk membeli sepeda motor akan sangat terbantu dan puas (satisfaction) pada nilai guna dari sepeda motor tersebut namun beda halnya dengan seseorang atau rumah tangga yang memiliki anggaran yang cukup untuk membeli mobil dia menyatakan puas atau kurang puas jika ingin merasakan mobil yang lebih mewah. 


\section{KESIMPULAN}

Pada bagian ini menguraikan tentang (a) simpulan penelitian, (b) implikasi hasil penelitian dan (c) saran-saran

\section{Kesimpulan}

Tingkat kesejahteraan rumah tangga bisa diukur dari beberapa indikator utama yakni kepemilikan kekayaan material, rasa aman dalam keluarga, saling mencintai dan menyayangi, dan aktualisasi kepala rumah tangga dalam eksistensi dalam keluarga dan masyarakat.

Faktor yang dominan yang menentukan kesejahteraan rumah tangga, bisa diurutkan berdasarkan besarnya nilai faktor loading yakni kepemilikan kekayaan material, saling mencintai, aktualisasi keluarga, dan rasa aman di keluarga.

\section{Saran - Saran}

Berdasarkan hasil penelitian bisa disarankan sebagai berikut:

1. Untuk menciptakan keluarga yang sejahtera disarankan agar kepala rumah tangga memberikan perhatian pada kepemilikan kekayaan dan assset rumah tangga, karena terbukti bahwa faktor ini menjadi salah satu faktor dominan dalam penentuan kesejahteraan rumah tangga.
2. Walaupun faktor kepemilikan kekayaan fisik, tidak bisa dipungkiri faktor psikologis, seperti rasa saling mencintai, rasa eksistensi kepala rumah tangga di keluarga dan rasa aman tetap harus menjadi faktor yang harus diperhatikan dalam hubungan interaksi dalam keluarga.

\section{DAFTAR PUSTAKA}

Bappenas. 2007. Laporan Perkembangan Pencapaian Milleneum Development Goals Indonesia 2007. Jakarta: UNDP-Bappenas

BKKBN. 1981. Sejarah Perkembangan Keluarga Berencana dan Arah Pengembangan Kependudukan. Jakarta: BKKBN

BPS. 2005. Sumatera Barat Dalam Angka, 2004/2005. Padang: BPS Sumatera Barat

Byrne, Barbara M. 1998. Structural Equation Modeling with RISREL, PRELIS AND SIMPLIS: Basic concepts, applications and programmng. Mahwah, New Jersey, London: Lawrence Erlbaum Associates

Cahyat,Ade. 2004. Bagaimana kemiskinan diukur?,Beberapa model penghitungan kemiskinan di Indonesia, Bogor: Poverty \& 


$\begin{array}{lr}\text { Decentralization } & \text { Project } \\ \text { CIFOR (Center } & \text { for } \\ \text { International } & \text { Forestry } \\ \text { Research) } & \text { BMZ } \\ \text { (Bundesministerium } & \text { für } \\ \text { Wirtschaftliche } & \\ \text { Zusammenarbeit } & \text { und } \\ \text { Entwicklung) } & \end{array}$

Cahyat, Ade dan Gonner, Chrtian serta Haug, Michaela. 2007. Mengkaji Kemiskinan dan Kesejahteraan Rumah Tangga dengan Contoh dari Kutai Barat, Indonesia. BogorL Center for International Forestry Research Jl. CIFOR, Situ Gede, Sindang Barang Bogor Barat 16115, Indonesia

Case, Karl E dan Ray C. Fair (2004) Prinsip-prinsip Ekonomi Makro,alih bahasa, Berlian Muhamad. Jakarta : PT Indeks Kelompok Gramedia

Cochran, William G. 2005. Teknik Penarikan Sampel. Edisi Indonesia. Jakarta: UI Press

Foa, U. B., J. M. Converse, E. Tornblom and E. G. Foa: 1993, Resource Theory: Explorations and Applications. San Diego: Academic Press

Hair, Jr, J. F., R. E Anderson R. L. Tatham \& W. C Black.2006. Multivariate Data Analysis 6 th. New Jersey: PracticeHall,Inc.
Hornik, Jacob, Cohen, Erik H. dan Amar, Reuven. 2007. A Facet Metatheoretical Approach to Advance Consumer Behavior Knowledge. Psychology \& Marketing, Vol. 24(9): 787813 (September 2007) Published online in Wiley InterScience (www.interscience.wiley.com) (C) 2007 Wiley Periodicals, Inc. DOI: $10.1002 /$ mar.20184

Jhingan, M.L.2003, Ekonom Pembangunan dan Perencanaan. Jakarta : PT Raja Grafindo Persada

Keynes, Jhon Maynard. 1991. Teori Umum Mengenai Kesempatan Kerja, Bunga dan Uang/Edisi Indonesia, Yogyakarta : Gajah Mada University Press.(terjemahanWillem $\mathrm{H}$. Makaliwe)

Maslow H. Abraham (1954) A Theory of Human Motivation, Pshichological Review. New York: Harper \& Row.

Mincer, Jacob, (I974/1977) Schooling, Experience, and Earnings (New York: Columbia University Press for the National Bureau of Economic Research)

Narayan, Deepa and Lant Pritchett. 1999. SocialCapital: Evidence and Implications. in Dasgupta 
and Serageldin, eds. op. cit. pp. 269- 95.

Nicholson, Walter. 2002. Mikroekonomi intermediate dan aplikasi : alih bahasa Ign Bayu mahendra. Jakarta : Penerbit Erlangga
Pindyk, Robert S. and Daniel Rubinfeld. 2005. Mikroekonomi, (edisi Indonesia, Nia Kurnia dewi. Jakarta : PT Indeks.

Pigou,A.C.1952. The Economics of Welfare. London:Macmillan

Rettig, Kathryn D. dan Bubolz, Margaret M. 1983. Interpersonal Resource Exchanges as Indicators of Quality of Marriage. Journal of Marriage and the Family, Vol. 45, No. 3 (Aug., 1983), pp. 497-509.

http://www.jstor.org/stable/35 1655

Rettig, Kathryn D. dan Leichtentritt Ronit D. 1999. A Generas/ Theory For Perceptual Indicatorof Family Life Quality. Social Indicators Research 47: 307-342, 1999. Kluwer Academic Publishers. Printed in the Netherlands.

Sen, Amartya. 1984. The Living Standar,Oxpord Economic, Paper,36. Supplement.74-90
Stiglitz, Joseph E. 2006. Dekade Keserakahan era -90-an dan Awal Mula Petaka Ekonomi,penerjemah AanSuhaeni. Jakarta: PT Cipta Lintas Wacana

Smith, Adam.1776. An Inquiry into the Nature and Causes of the Wealth of Nations. http://socserv.mcmaster.ca/e con/ugcm/3\|l3/smith/dugald, Dowload tangal 5 Januari 2007

Todaro, Michel P. 2003. Pembangunan Ekonomi,edisi Indonesia. (alih bahasa : Harris munandar). Jakarta: Erlangga.

Yuen,Felice C Alison Pedlaf, and Roger C. Mantiell. 2005. Building Community and Social Capital through Children's Leisure in the Context of an International Camp. University of Waterloo: Journal of Leisure Research. Vol 37 no 4.pp/ 494-51-8

Yusuf, S.A. 2008. Social Capital and Household Welfare in Kwara State, Nigeria: Department of Agricultural Economics, University of Ibadan, Ibadan, Nigera J. Hum. Ecol., 23(3): 219-229

Wijanto, Setyo Hari. 2007. Struktural Equation Modeling dengan Lisrel 8,8. :Yogyakarta, Graha Ilmu 